\title{
Public Service Management through Making Identity Cards During Covid-19 in Bandar Lampung City, Indonesia
}

\author{
Muhammad Ardiansyah ${ }^{1}$, Irsandi ${ }^{1}$, Muhammad I. Martadinata ${ }^{2}$, \\ Esti Melinda $^{1} \bowtie$, Agustuti Handayani ${ }^{1}$ \\ ${ }^{1}$ University of Bandar Lampung, \\ Z.A. Pagar Alam Street No. 29 Labuhan Ratu, Lampung, Indonesia, 35142 \\ ${ }^{2}$ Palembang Aviation Polytechnic, \\ Adi Sucipto Street No. 3012, Sukodadi, Palembang, Indonesia, 30961 \\ \estimelinda1987@gmail.com
}

\begin{abstract}
The Covid-19 pandemic has forced every resident in Indonesia to have an Electronic Identity Card because it is one of the requirements for disbursing social assistance to residents affected by Covid-19. However, the Identity Card service in Bandar Lampung City is still experiencing several problems, such as long queues and a slow system. The pandemic condition should be used as a positive momentum in improving services that were initially face-to-face and caused long queues and then switched to an online system using Information Technology. This study uses a qualitative approach with data validity techniques using source triangulation. The results showed that the Department of Population and Civil Registration of Bandar Lampung City has not fully worked well but has carried out service standards in service management in making Identity Cards by reducing face-to-face service hours and limiting 60 people per day, diverting consulting services and complete files. Through the Whatsapp service, the public is also free of charge as well as providing service facilities and infrastructure according to health protocol standards and placing officers at the service counter in accordance with their competencies as well as periodic training for service counter officers. The results of this study also revealed that there was a very rapid policy change that caused a lack of socialization to the community in Bandar Lampung City, as well as a lack of awareness of the public who needed services on the importance of obeying health protocols.
\end{abstract}

Keywords: public service, identity cards, Covid-19, Indonesia

Conflicts of interest: The authors declared no conflicts of interest.

Article history:

The article was submitted on 21.06.2021. The article was accepted on 05.08.2021.

For citation: Ardiansyah M., Irsandi, Martadinata M.I., Melinda E., Handayani A. Public Service Management through Making Identity Cards During Covid-19 in Bandar Lampung City, Indonesia. RUDN Journal of Public Administration. 2021;8(4):442-451. DOI: 10.22363/2312-8313-2021-8-4$442-451$

\section{Introduction}

Currently the government is obliged to provide public services through bureaucrats to the community in order to meet all the basic needs of society. The existing service process must be able to uphold the values of professionalism, the 
quality of service products must be maintained and the cost and time of completion are in accordance with the standard [1]. By applying these values, an efficient and effective service will be created. Public services will develop rapidly, if supported by information technology commonly known as smart cities. The application of a smart city is a form of excellent service, in administrative services in the population system [2].

The Population Administration System is an activity to organize and regulate documents and data regarding population through various activities such as population registration, population administration management, and utilization of population databases. The use of the database is intended for the community service process, development programs as well as for legal certainty on the civil rights of citizens, as well as the population administration system as an effort to provide population information for the benefit of national development [3].

The quality of the administration of the population administration system must be well guaranteed because it greatly affects the public services that will be received by the community in the future. The population administration system includes birth certificates, Identity Cards, Family Cards, and Child Identity Cards. Fulfilling the quality of the administration of the population administration system is a general task of the government related to the civil rights of citizens. For this reason, population administration must be owned by all Indonesian people so that it can be used for daily life, and one of them is the Identity Card [4]. Identity Card is an identity card owned by the community, made computerized and has special specifications and formats. Because this National Identity Card has been protected by a special security system because it involves the identity of a person who is officially enforced in the country of Indonesia.

The Covid-19 outbreak is happening all over the world and its effects are still being felt today. The Covid-19 outbreak has had implications for the life sector [5]. Likewise with the existing work system in the government sector. The government is required to be adaptive in dealing with emerging challenges, namely related to public services. The government must be able to provide excellent service although it must also be oriented to the safety of government employees and the community. This application reduces the intensity of meetings between service providers and public service recipients. Conditions like this must be used as a positive momentum in optimizing public services, which were initially more face-to-face and then switched to an online system using Information Technology.

Currently, Population Administration Services related to Electronic Identity Cards have many problems. The problems experienced by each region are different. Problems with Identity Cards often occur in Bandar Lampung City, Indonesia. Before the pandemic, the people of Bandar Lampung City complained about the long queues, the system was very slow, and they still used a certificate to replace the Identity Card when they needed Electronic Identity Card services in Bandar Lampung City. Moreover, this pandemic also forces every resident to have an Identity Card, so its existence is very important for every citizen, because the Electronic Identity Card is one of the requirements for disbursing social assistance to residents affected by the Covid-19 outbreak. 


\section{Research Methods}

The type of research in this study is qualitative, using this qualitative approach to facilitate researchers in collecting data. Describe, identify and find new things that have not been discovered by previous researchers [6]. In the midst of the condition of the Indonesian state being faced with the Covid-19 pandemic, researchers tried to carefully collect data using free interview techniques, collect existing documents and conduct literacy studies. Interviews have been conducted with informants using telephone and video call media. Informants also helped send some documentation such as reports and some photos to researchers. To support the results of the interviews, the researchers also collected information from books, journals and online media.

\section{Theoretical Review}

The concept of public service has the meaning of a series of activities provided by the government in order to meet the needs of the community based on laws or government regulations. Service management is defined as the application of science and art in formulating a plan and implementing the plan by coordinating and other activities to achieve goals. Because they want to achieve service goals, public services must meet service standards. Public service standards consist of: service procedures, completion time. Service costs, service products, facilities and infrastructure, as well as officer competencies [7].

This public service has been regulated by Law Number 25 of 2009 concerning Public Services, in which it is regulated on Public Service Standards, as a guideline for implementation, and regarding the assessment of the quality of services provided to the community, so that services that are easy, fast, affordable, and measurable can be realized. As for the several components in this Service Standard, at least: Legal basis, requirements, systems, mechanisms, and procedures; Completion period; Fees or tariffs; Service products; Facilities, and/or facilities; Service guarantees related to service certainty; Security assurance, as well as safety being a commitment can provide a sense of security, free from danger, and risk; job evaluation. This service standard is supported by: awareness of the apparatus; Rules on which to base; Organization which is the tool/system which is the mechanism; Abilities, and Skills; income; and service facilities [8].

Factors inhibiting the implementation of this public service standard; lack of awareness of the apparatus towards their duties and obligations; Inadequate systems, procedures and work methods; Organization of service tasks that are not yet appropriate so that they overlap; The income of the apparatus is not sufficient to meet the necessities of life; Inadequate ability of employees to complete tasks assigned by their superiors; unavailability of adequate facilities [9].

\section{Research results and discussion Management of Electronic Identity Card Services in the Era of the Covid-19 Outbreak}

Services are basically organized on the basis of convenience between service providers and public service recipients [10]. Service standards need to be 
maintained by service providers, and must be known by public service recipients. Therefore, service recipients must understand everything related to the service. In the era of the Covid-19 outbreak, many policies are changing rapidly. So that service recipients must be willing to seek information about services in the era of the Covid-19 pandemic. Many relaxations of the Standard Operating Procedure have been carried out to maintain services so that they can run well but do not override health protocols.

Service Procedure, is a standard thing that must be agreed upon for service providers and recipients [11]. So that in the service a Standard Operating Procedure is established for the smooth running of the services provided, based on the Bandar Lampung City Regional Regulation Number 9, 2015 concerning the Implementation of Population Administration Services, and Civil Registration regarding the Issuance of Electronic Identity Cards. After recording, the public can print their Identity Cards. The following is the Standard Operating Procedure (SOP) regarding the mechanism and procedure of the Identity Card service:

1. The applicant may submit all required documents for managing the Identity Card to the resident officer;

2. The officer carries out the process of issuing the Identity Card to the applicant by giving a receipt to the public (applicant) during processing;

3. The community (applicant) submits the receipt for this collection to the population officer in accordance with the stipulated time (completed with the Identity Card);

4. The Population and Civil Registry Service officer then hands over the completed Resident Identity Card

A mobile car with all items specially designed for recording and recording Electronic Identity Cards so that people no longer need to go to the Population and Civil Registration Office of Bandar Lampung City. Employees of the Population and Civil Registry Office usually visit several special areas or places, such as: schools, nursing homes, hospitals, or urban village areas where the ownership of Electronic ID cards is still low. The following is a mobile service car that is used to serve the Electronic Resident Card with a direct system.

However, since the pandemic, this mobile public service car will no longer operate temporarily until an undetermined time limit. Direct service via mobile car is an innovative form of service. Another breakthrough program carried out by the Department of Population and Civil Registration in picking up people for public services is by placing special counters in each region, bringing the total special counters to 57 counters according to the number of urban villages in Bandar Lampung City. The Department of Population and Civil Registration places noncivil servant commonly known as Activity Operational Assistance Personnel (TPOK) to facilitate population administration services. This activity has many benefits, because the community does not need to come to the Population and Civil Registry Office several times to register and register, but instead comes directly to the region to submit files and later on schedule to the Population and Civil Registry Office. Office to carry out the recording and printing process.

In the Covid-19 Pandemic Era, the service procedure experienced a relaxation of the SOP. slightly different from before the pandemic. Face-to-face services are 
reduced, because now information and file preparation is done online. This is to avoid accumulation in the Population Administration and Civil Registration Services. The number of people who can get services at the Population Administration and Civil Registration Services is limited to a maximum of 60 people. The ball pick-up service in the society is also limited in its service hours, Monday to Thursday from 08.00 to 13.00 , while for Friday it starts at 07.30 until 10.30. For consultations and registration for recording the Electronic Identity Card, it can be done through the WhatsApp number that has been specially prepared for public services. Before submitting the required documents for the completeness of making an Electronic Identity Card, the applicant must fill out a statement letter signed on 6000 stamp duty.

The completion time is how long it takes to process the Electronic Identity Card. The completion time is determined from the time the application is submitted until the completion of the service. The time required for the completion of the Electronic Identity Card processing based on the SOP is four days. However, in its implementation, Population Administration and Civil Registration Services takes about five working days to 2 weeks. This depends on the conditions of the available blanks. In the Pandemic era, the completion of recording and printing of Electronic Identity Cards can be completed on time according to the existing SOPs as long as the required files are complete and there are no problems. This happens due to the limitation of applicants every day, so the service rate is flat.

Service costs based on Law Number 25 of 2009 concerning public service standards, service costs are costs incurred for the continuity of the service process carried out by service providers. The service fee includes a breakdown of the rates stipulated in the provision of services by the Department of Population and Civil Registration of Bandar Lampung City. The service fee for making an Electronic Identity Card is free of charge. This is in accordance with the Decree of the Head of the Population and Civil Registration Office of Bandar Lampung City Number 14 of 2020 concerning the Determination of Service Standards for the Types of Population Administration and Civil Registration Services carried out by the Population and Civil Registration Office of Bandar Lampung City.

If there are some people who state that the processing of Electronic Identity Cards is paid during the pandemic, this is disinformation. It's said to be disinformation Incomplete news. Because in fact, all services at the Department of Population and Civil Registration are free of charge. Because apart from the rules governing free services, the Population and Civil Registry Service is included in the Regional Government Organization and is a Corruption-Free Integrity Zone. So there is no activity of receiving money directly to employees. If there are people who say that making Electronic Identity Cards is paid, they usually use the services of brokers.

Facilities are the main important things that must be provided by the Department of Population and Civil Registration of Bandar Lampung City in supporting the implementation of effective and efficient public services so as to make people who want to take care of Electronic Identity Cards comfortable. The existing infrastructure facilities at the Population and Civil Registration Office are very adequate, such as: the availability of a large parking lot, a comfortable waiting 
room with children's play facilities, lactation rooms, facilities for the disabled, lanes for the elderly and pregnant women, wifi facilities, toilets and canteens. Specifically for the Electronic Identity Card service itself, Department of Population and Civil Registration of Bandar Lampung City provides 57 computers in the special service room for Electronic Identity Card services, equipped with printers and scanners. This is done to reduce the number of queues because 1 computer is used for 1 area. Activity Operational Assistance Personnel (TPOK) employees in each region are also equipped with computer facilities, printers and scanners as well as an intranet network from the village computer which is directly connected to the computer in the service room of the Population and Civil Registration Service. The existence of this intranet network makes it easier to coordinate and solve problems if in an area, Operational Assistance Personnel (TPOK) officers encounter problems when serving people who are taking care of Electronic Identity Cards. The recording machines and printing machines for Electronic Identity Cards at the Department of Population and Civil Registration are also very adequate. If there is a queue in the waiting room, this is due to two reasons, namely the first, there is an empty blank from the center. Second, everyone takes care simultaneously and is not limited by the Department of Population and Civil Registration of Bandar Lampung City himself for his daily services. When the blank is available, the service rate becomes very high (many do the management). However, with the routine ball pick-up activities, lowering the mobile car fleet and the presence of Activity Operational Assistance Personnel (TPOK) employees, non-civil servants in each area, this has minimized the occurrence of long queues. So that people just come to the Department of Population and Civil Registration for the recording and printing of Electronic Identity Cards only.

Based on the Service SOP at the Population and Civil Registration Service, it is explained that the infrastructure needed for Electronic Identity Card services are document cabinets, filing racks, desks, chairs, computers, printers, and office stationery. For services during the pandemic, facilities and infrastructure are adjusted to health protocols, such as the provision of thermal guns, hand sanitizers, and sinks for washing hands. Since the pandemic period, the waiting room which is usually operated inside has been moved outside with strict health protocol procedures. Every day before the office is opened and after the service is finished, all office areas are sprayed with disinfectant by employees of the Population and Civil Registration Office as an effort to prevent the Corona virus.

Implementing competence, is the minimum ability possessed by service providers to support the running of services properly [12]. Based on the existing SOP, employees at the service counter must have a minimum formal education of high school or equivalent, service oriented, have an empathetic attitude, be communicative and able to operate computers and be able to work in teams. The Population and Civil Registry Service employees who are at the service counter are selected people who have been selected according to the existing SOP. In addition, the Population and Civil Registry Office routinely conducts training to increase the knowledge and skills of its employees in terms of Internet Technology. Likewise, during a pandemic, training continues with due observance of health protocols. By increasing the capacity of its employees with this training, it is hoped that 
employees will be ready to provide excellent service to the people who carry out management at the Population and Civil Registry Office of Bandar Lampung City.

Service guarantee is the most important thing in public service. Where in the implementation of services, service providers must provide certainty in accordance with service standards. Service guarantee is a guideline in guaranteeing the community that the services received are free from illegal fees (extortion) [13]. So that the community is comfortable and Population and Civil Registry Office employees can provide excellent service. Moreover, Population and Civil Registry Office is included in the Integrity zone. The Department of Population and Civil Registration guarantees that the services provided to the community are free from corruption and there are no illegal fees as stated on the banner which aims to provide comfort to the community.

Performance evaluation is a process used by leaders to determine whether an employee is doing his job in accordance with his duties and responsibilities [14; 15]. Job evaluation is always carried out by the Population and Civil Registration Office of Bandar Lampung City by paying attention to several public complaints submitted through the suggestion/complaint box or virtual complaint box submitted online. One of the actions taken from the results of the evaluation is the existence of services in each village by placing an Operational Assistance Personnel (TPOK) officer which is a form of the ball pick-up program. Another pick-up program is the round-trip Resident Identity Card service which is carried out to places such as schools, hospitals and some nursing homes.

Work evaluation is held every month with internal coordination meetings related to the implementation of program activities and services, overall work evaluation is carried out every year as well as evaluating the work of non-civil servant Operational Assistance Personnel (TPOK) employees, whether their contracts will be extended for the next year or terminated. During the pandemic, work evaluations regarding services are more often carried out due to conditions that contain uncertainty such as the rapid changes in regulations from the center and the internal conditions of the office itself. Which of these situations must be responded to quickly [16]. So that public services are not disrupted.

\section{Factors that influence Public Service Management through the Identity Card of the Population and Civil Registration Office of Bandar Lampung City When the Covid-19 Outbreak}

\section{Supporting Factors}

Supporting factors are things that need to be considered in public services which can support services to be very optimal so that people are satisfied with the services provided. The supporting factors for the management of electronic Identity Card services at the Population and Civil Registry Office of Bandar Lampung City are:

1) Fulfillment of facilities and infrastructure. Both in terms of a good building, a large parking area, an adequate and comfortable waiting room, a lactation room, as well as supporting equipment for electronic Identity Card services (a machine for recording and recording Identity Cards that has been 
integrated into the center). In the Covid-19 Pandemic Era, infrastructure facilities for health protocols have been fulfilled properly, such as checking body temperature with a thermal gun, hand washing sink, and hand sanitizer in the service room area.

2) Competence and number of employees. The competence of employees in operating the programs is quite good, because periodically there are trainings held to upgrade their ability to operate and the number of officers is very adequate. This is sufficient, the cost in the service is free so that it makes the community comfortable in managing electronic Identity Cards.

\section{Obstacle factor}

Inhibiting factors always appear in public services which can hinder services that should run in accordance with the desired goals. Service inhibiting factors in the era of the Covid-19 pandemic are: 1). Number of policies-new policies that must be adapted, and changes to these policies sometimes cause disinformation to the public. Such as changes in service hours and several service procedures that switch to an online system as well as service restrictions at the Population and Civil Registry Office. Population and Civil Registry Office should conduct socialization both offline and online by cooperating with print and online media. 2) The community's mindset in accepting change is still not good, so some of the problems that are often encountered in the field are: the community does not accept that there is a change in service hours and service procedures that have been set taking into account the safety of all parties, the community is also less aware of the implementation of health protocols and services. So that not a few people forget to bring a mask or lower the mask to their chin while waiting.

\section{Conclusion}

Management of Electronic Identity Card (KTP-el) Services at the Population and Civil Registration Office of Bandar Lampung City during the covid-19 pandemic are as follows: 1) Service procedures, there is convenience in managing Electronic Identity Cards by coming with a Family Card, eliminating mobile car and reduce service hours and limit applicants to only 60 people per day, 2) Completion time, with 60 applicants, the completion of the Electronic Identity Card can be in accordance with the SOP, which is 4 days, 3) Service fees, free of charge, 4) Infrastructure / The facilities are very adequate in terms of service and are equipped with standard health protocols, 5) Competency for implementing a minimum of Senior high school and equipped with routine training on IT, 6) Service, this is service certainty and corruption-free certainty. 7) Performance evaluation, carried out every time because during the pandemic many policies change quickly.

\section{REFERENCES}

1. Dinas Kependudukan dan Catatan Sipil Kota Bandar Lampung. URL: https://disdukcapil. bandarlampungkota.go.id. Accessed: 11.06.2021 (In Indon).

2. Pasolong H. Teori Administrasi Publik. Bandung: Alfabeta; 2018 (In Indon).

3. Mustafa D. Birokrasi Pemerintahan. Bandung: Alfabeta; 2017 (In Indon).

4. Wibawa S. Administrasi Negara Isu-isu Kontemporer. Yogyakarta: Graha Ilmu; 2016 (In Indon).

5. Zahrotunnimah Z. Indonesian Government Bureaucracy Efforts to Prevent Covid-19 at the Beginning of the Pandemic Period. RUDN Journal of Public Administration. 2021;8(2):153166. DOI: $10.22363 / 2312-8313-2021-8-2-153-166$ 
6. Creswell J.W. Research Design: Pendekatan Kualitatif, Kuantitatif, Dan Mixed. Yogyakarta: PT Pustaka Pelajar; 2010 (In Indon.).

7. Setiawan R. Peranan Etika Aparatur Sipil Negara Dalam Pelayanan Publik Pada Dinas Kependudukan Dan Catatan Sipil (Disdukcapil) Kota Bandar Lampung. Jurnal e-JKPP. 2016;2(2):46-57 (In Indon.).

8. Setiawan R. Partisipasi Publik Dalam Program Bantuan Listrik Pedesaan Masyarakat Kabupaten Mesuji. Jurnal e-JKPP. 2017;3(3):82-92 (In Indon.).

9. Setiawan R., Melinda E. Optimization of the Implementation of Village Government in Indonesia. RUDN Journal of Public Administration. 2020;7(4):352-360.

10. Santoso P. Administrasi Publik Teori dan Aplikasi Good Governance. Bandung: Rafika Aditama; 2008 (In Indon).

11. Setiawan R., Abdurahman A., Pertiwi P.G., Saputri S. Reaksi Perekonomian Rusia Ditengah Pandemi Covid-19. 'Adalah. 2020;4(1):258-291 (In Indon).

12. Hikmat H. Strategi Pemberdayaan Masyarakat. Bandung: Humaniora Utama Press; 2004 (In Indon.).

13. Hulu V. A., Patuninno T. R., Puspasari D., Juniyanto N., Pramudita L. T. A. Menggagas Revolusi Mental Birokrasi Melalui Konsep Competitive Agile Leadership. Ministrate: Jurnal Birokrasi Dan Pemerintahan Daerah. 2020;2(1):29-37. DOI: https://doi.org/10.15575/ jbpd.v2i1.8050

14. Farida I., Etiawan R. Leadership in Cope With Prostitute in Social Department of Bandar Lampung. International Journal of Social Sciences and Development. 2018;2(1):1-8. DOI: 10.24967/saburaiijssd.v2i1

15. Setiawan R., Faizah S.I.N., Pertiwi G.P. Manajemen Sistem Registrasi Penduduk Asing Melalui Elektronik Digital di Rusia. EXPERT: Jurnal Manajemen Sistem Informasi dan Teknologi. 2020;10(2):1-4. DOI: http://dx.doi.org/10.36448/jmsit.v10i2.1555 (In Indon.).

16. Sumarto H. Inovasi, Partisipasi, dan Good Governance. Jakarta: Yayasan Obor Indonesia; 2018 (In Indon.).

\section{Information about the authors:}

Muhammad Ardiansyah - Lecturer at the Department of Public Administration, University of Bandar Lampung (Indonesia) (ORCID ID: 0000-0001-5117-325X) (e-mail: m.ardiansyah@ubl.ac.id)

Irsandi - Lecturer at the Department of Business Administration, University of Bandar Lampung (Indonesia) (ORCID ID: 0000-0002-3278-2188) (e-mail: masayu@ubl.ac.id).

Muhammad I. Martadinata - Lecturer at the Department of Engineering, Palembang Aviation Polytechnic (Indonesia) (ORCID ID: 0000-0002-5934-5893) (e-mail: indrakoe69@gmail.com)

Esti Melinda - Lecturer at the Department of Public Administration, University of Bandar Lampung (Indonesia) (ORCID ID: 0000-0002-9675-045X) (e-mail: estimelinda1987@gmail.com)

Agustuti Handayani - Lecturer at the Department of Public Administration, University of Bandar Lampung (Indonesia) (ORCID ID: 0000-0002-8179-0934) (e-mail: agustuti.handayani@ubl.ac.id)

\section{Управление государственными услугами посредством изготовления удостоверений личности во время пандемии Covid-19 в городе Бандар-Лампунг, Индонезия}

\section{М. Ардиансях ${ }^{1}$, Ирсанди $^{1}$, М.И. Мартадината ${ }^{2}$, Э. Мелинда ${ }^{1} \bowtie$, А. Хандаяни ${ }^{1}$}

${ }^{1}$ Университет Бандар-Лампунг, 35142 Индонезия, Лампунг, 3.А. ул. Пагар Алам, 29

\footnotetext{
${ }^{2}$ Палембангский авиационный политехнический институт, 30961 Индонезия, Палембанг, Сукодади, ул. Ади Сукипто, 3012

\estimelinda1987@gmail.com
}

Аннотация. Пандемия Covid-19 вынудила каждого жителя Индонезии завести электронную идентификационную карту как одно из требований для выплаты социальной помощи 
жителям, пострадавшим от коронавируса. Однако служба удостоверений личности в городе Бандар-Лампунг все еще сталкивается с рядом проблем, таких как длинные очереди и медленная работа электронной системы. Пандемию следует использовать как положительный импульс для улучшения услуг, которые первоначально предоставлялись лично и приводили к длинным очередям, а затем были переведены на онлайн-систему с использованием информационных технологий. В этом исследовании используется качественный подход с методами проверки достоверности данных с использованием триангуляции источников. Результаты показали, что Департамент народонаселения и регистрации актов гражданского состояния города Бандар-Лампунг работал с недостаточно высокой эффективностью, однако соблюдал стандарты обслуживания в управлении услугами по изготовлению удостоверений личности за счет сокращения часов личного обслуживания и ограничения в 60 человек в день, перенаправив усилия на консультационные услуги и заполнение профилей. Через мессенджер Whatsapp общественности бесплатно предоставляются услуги в соответствии со стандартами протокола здравоохранения. Размещение сотрудников у стойки обслуживания проводится в соответствии с их компетенцией, а также периодически проводится обучение сотрудников службы поддержки. Проведенное исследования также показало, что произошло очень быстрое изменение политики, которое привело к недостаточной социализации общины в городе Бандар-Лампунг, а также к недостаточной осведомленности общественности, нуждающейся в услугах, о важности соблюдения протоколов здравоохранения.

Ключевые слова: государственная служба, удостоверения личности, Covid-19, Индонезия

Заявление о конфликте интересов: Авторы заявляют об отсутствии конфликта интересов.

\section{История статьи:}

Статья поступила в редакцию: 21.06.2021. Статья принята к публикации: 05.08.2021.

\section{Для цитирования:}

Ardiansyah M., Irsandi, Martadinata M.I., Melinda E., Handayani A. Public Service Management through Making Identity Cards During Covid-19 in Bandar Lampung City, Indonesia // Вестник Российского университета дружбы народов. Серия: Государственное и муниципальное управление. 2021. T. 8. № 4. С. 442-451. DOI: 10.22363/2312-8313-2021-8-4-442-451

\section{Информация об авторах:}

Мухаммад Ардиансьях - преподаватель кафедры государственного управления Университета Бандар-Лампунг (Индонезия) (ORCID ID: 0000-0001-5117-325X) (e-mail: m.ardiansyah@ubl.ac.id) Ирсанди - преподаватель кафедры делового администрирования Университета Бандар-Лампунг (Индонезия) (ORCID ID: 0000-0002-3278-2188) (e-mail: masayu@ubl.ac.id).

Мухаммад И. Мартадината - преподаватель инженерного факультета Палембангского авиационного политехнического института (Индонезия) (ORCID ID: 0000-0002-5934-5893) (e-mail: indrakoe69@gmail.com)

Эсти Мелинда - преподаватель кафедры государственного управления Университета БандарЛампунг (Индонезия) (ORCID ID: 0000-0002-9675-045X) (e-mail: estimelinda1987@gmail.com)

Агустути Хандаяни - преподаватель кафедры государственного управления Университета Бандар-Лампунг (Индонезия) (ORCID ID: 0000-0002-8179-0934) (e-mail: agustuti.handayani@ubl.ac.id) 